\title{
FORMATION OF INVESTMENT PORTFOLIOS OF TWO ASSETS BASED ON FORECAST RETURNS USING THE ARFIMA-GARCH MODEL
}

\author{
Robert V. Garafutdinov \\ Perm State University, Perm, Russian Federation
}

\begin{abstract}
The paper tests the hypothesis that the formation of investment portfolios of two assets based on predicted returns obtained using fractal models with conditional heteroscedasticity (ARFIMA-GARCH) allows to obtain portfolios with better characteristics than those obtained using the ARFIMA model. A computational experiment on artificial data and real data from the Russian stock market was carried out. The software implementation of the hypothesis testing algorithm was carried out using Python and R programming languages. The following results were obtained. Average absolute forecast error of the ARFIMA-GARCH model differs from the ARFIMA model error within the limits of error, statistically significant difference is not revealed (it is true for both model and real data). At the same time, portfolios formed using the GARCH model have, on average, higher returns, and a better return to risk ratio in comparison with portfolios formed using the ARFIMA model. Therefore, the hypothesis about the benefits of fractal GARCH models is not rejected.

Key words: investment portfolio, financial time series, return forecasting, fractal econometric models, ARFIMA, ARFIMA-GARCH.

Citation. Garafutdinov R.V. Formation of Investment Portfolios of Two Assets Based on Forecast Returns Using the ARFIMA-GARCH Model. Vestnik Volgogradskogo gosudarstvennogo universiteta. Ekonomika [Journal of Volgograd State University. Economics], 2021, vol. 23, no. 2, pp. 130-136. DOI: https://doi.org/10.15688/ek.jvolsu.2021.2.11
\end{abstract}

\section{ФОРМИРОВАНИЕ ИНВЕСТИЦИОННЫХ ПОРТФЕЛЕЙ ИЗ ДВУХ АКТИВОВ НА БАЗЕ ПРОГНОЗНЫХ ДОХОДНОСТЕЙ С ПРИМЕНЕНИЕМ МОДЕЛИ АRFIMA-GARCH}

\section{Роберт Викторович Гарафутдинов}

Пермский государственный национальный исследовательский университет, г. Пермь, Российская Федерация

\footnotetext{
Аннотация. В работе проверяется гипотеза о том, что формирование инвестиционных портфелей из двух активов на базе прогнозных доходностей, полученных с применением фрактальных моделей с условной гетероскедастичностью (ARFIMA-GARCH), позволяет сформировать портфели с лучшими характеристиками, чем портфели, полученные с применением модели ARFIMA. Был проведен вычислительный эксперимент на искусственных и реальных данных российского фондового рынка. Программная реализация алгоритма проверки гипотезы осуществлена с использованием языков программирования Руthon и R. Были получены следующие результаты. Средняя абсолютная ошибка прогноза модели ARFIMA-GARCH отличается от ошибки модели ARFIMA в пределах погрешности, статистически значимая разница не выявлена (справедливо и для модельных, и для реальных данных). В то же время портфели, сформированные с использованием модели GARCH, в среднем обладают большей доходностью и лучшим соотношением доходности и риска, чем портфели, полученные с использованием модели ARFIMA. Поэтому выдвинутая гипотеза о преимуществах фрактальных GARCH-моделей не отвергается.

Ключевые слова: инвестиционный портфель, финансовые временные ряды, прогнозирование доходностей, фрактальные эконометрические модели, ARFIMA, ARFIMA-GARCH.
} 
Цитирование. Гарафутдинов Р.В. Формирование инвестиционных портфелей из двух активов на базе прогнозных доходностей с применением модели ARFIMA-GARCH // Вестник Волгоградского государственного университета. Экономика. - 2021. - Т. 23, № 2. - С. 130-136. - (На англ. яз.). - DOI: https://doi.org/10.15688/ ek.jvolsu.2021.2.11

\section{Introduction}

The most important way to generate income in a market economy is to invest, which involves abandoning current consumption to generate future profits. Now, it is more important not just to receive income, but to guarantee it in unstable conditions along with hedging financial risks. The development of innovative methods of portfolio formation, which can provide a more accurate forecast of the financial result, becomes important.

Today the theory of optimal investment portfolio by Harry Markowitz, based on maximization of return on investment while minimizing risk [Markowitz, 1952; Aouni et al., 2018], remains the most widely used one. The value of risk is, as a rule, expressed by the standard deviation of profitability. When forming a portfolio, the task of optimization is solved and the structure of the portfolio is selected in such a way as to provide the best values of its performance, calculated by historical returns on assets. It is assumed that in the future the probabilistic price characteristics of these assets (mathematical expectation, standard deviation) will remain unchanged, the prices will behave in a similar way.

In practice, a portfolio optimized by historical prices will be optimal only if the future dynamics of returns will be a constant, and this prerequisite in life is impossible. We have suggested that if we extrapolate price series of assets included in the portfolio and calculate the target function not by historical returns but by predicted ones, the obtained portfolios should have more attractive characteristics (higher returns with lower risk) than with the classical model of average dispersion.

There are many methods to predict the dynamics of financial instruments. A promising approach to describing complex behavior of financial indicators was developed based on fractal theory. In [Garafutdinov et al., 2019], the ARFIMA fractal econometric model was used to predict the dynamics of stock exchange rates, the effectiveness of which, in comparison with non-fractal ARIMA, was confirmed, for example, in [Simonov et al., 2019a; Balagula, 2020]. The results of the research showed that the portfolio formed on such a forecast series has better parameters in comparison with the portfolio optimized on historical data.

It is known that the volatility of financial instruments yield, in addition to the properties of leptocourticity, persistence (presence of "long memory") and scale invariance, is characterized by the clustering effect [Simonov et al., 2019b], i.e. the property according to which large rate changes with high probability will follow big changes and small ones - small ones. This effect is like that of persistence, except that it is not the direction of change in the value of the indicator but its scattering that serves as a long-lasting value. In conditions of high volatility on financial markets, the GARCH model is often used for modeling the yield, where the dispersion of the modeled index depends on the previous values of both the index itself and its dispersion [Bollerslev, 1986]. As an equation of conditional mathematical expectation of the GARCH model can be ARFIMA, which allows to consider the fractal properties of the simulated process [Simonov et al., 2019a]. We have put forward a hypothesis that the ARFIMA-GARCH model allows us to obtain better portfolio characteristics than the standard ARFIMA. The purpose of this study is to test this hypothesis.

\section{Methods and data}

Let us describe the research methodology and data. We decided to consider the dynamics of monthly asset prices (by monthly price we mean the closing price on the first day of the month) from January 2009 to January 2020. It was decided to use monthly values for modeling the forecast profitability, because to identify the parameters of ARFIMA and GARCH models requires at least several dozens of observations. As the optimized characteristics of the portfolio we will take its annual return and standard deviation. The monthly return on an asset $r^{m}{ }_{t}$ is calculated by formula $r^{m}{ }_{t}=\frac{p^{m}{ }_{t}}{p^{m}{ }_{t-1}}-1$, where $p^{m}{ }_{t}$ is 
asset price in month $t$. To go from monthly to annual return, the formula $r_{t}^{y}=\left(\prod_{t=1}^{12}\left(1+r^{m}{ }_{t}\right)\right)-1$ is used. To estimate the annual risk of the asset, the formula of sampling standard deviation applied to a number of annual returns $\left\{r^{y}{ }_{t}\right\}$ is used.

Mathematical formulation of the task of investment portfolio optimization is described, for example, in the article [Semenenko, 2015]. In this study, optimization will be performed on three criteria: maximize the projected annual return; minimize the projected annual risk; maximize the yield/risk ratio (known as Sharp's ratio [Gubanova et al., 2016]). The portfolio's projected annual return in 2019 is calculated as a weighted average of the assets' projected annual returns. The portfolio's projected annual risk is calculated by series of historical annual return on assets (for 2009-2018, 10 values), to which are added the projected annual return in 2019, a total of 11 values. Criteria for comparing different portfolio models take the actual annual return of the portfolio in 2019 and the standard deviation of its annual return calculated by series of historical annual returns on assets with the addition of actual in 2019. Mathematical description of ARFIMA and GARCH models is given, for example, in [Simonov et al., 2019a].

Before moving on to experiments on real data of financial instrument rates, we decided to apply the Monte Carlo method, i.e. to test the hypothesis on artificial rows obtained with the help of computer simulation. The approach to optimization of portfolio structure by forecast series is based on the simple idea that the more accurate the forecast can give the model, the better-quality portfolio will be formed. That is why it was decided to first compare ARFIMA and ARFIMA-GARCH models by an average error when forecasting artificial and real financial series. The generated series were the implementation of fractal Brownian motion (fBm) with Hurst index $H=0.6$. The $\mathrm{fBm}$ model was chosen because it describes the dynamics of stock markets quite well [Chichaev et al., 2013]. Using the Python 3.8.5 programming language with $\mathrm{R}$ 4.0.2 inserts (for which the rpy2 package was used), we generated 1000 series of 133 values (this length corresponds to the number of monthly prices from January 2009 to January 2020). To simulate the prices of real financial assets, each element of the generated series was increased by the minimum value in the series and by one. Then these "price series" were transformed into "profitability series" of 132 elements. The first 120 values served as a training sample, the last 12 as a testing sample during model building and testing. The real series were the series of monthly returns on shares of 20 companies from the base of calculation of the MICEX Index as of 2020 August 1 with the history of not less than the beginning of 2009. The examples of artificial and real market "series of returns" are shown in Figure 1.

During the experiment, we compared 2 model implementations: $\operatorname{ARFIMA}(p, d, q)$ $\operatorname{GARCH}(1,1)$ from rugarch package in $\mathrm{R}$ and ARFIMA from arfima package in $\mathrm{R}$. The GARCH model with parameters $(1,1)$ is often

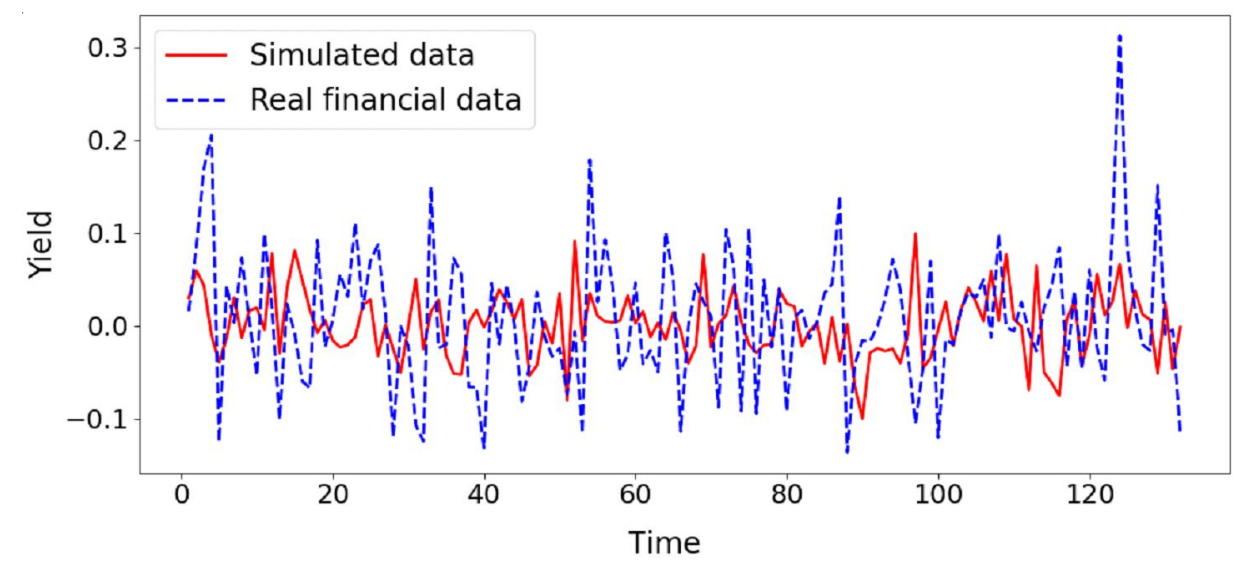

Fig. 1. Yields of artificial series and Gazprom ordinary shares (the ticker is GAZP) for the period from February, 2009 to January, 2020

Note. Compiled by the author. 
used in practice because of its ability to model the volatility clustering based on a small number of parameters [Simonov et al., 2019b]. In case of ARFIMA-GARCH, all model parameters were automatically determined by the algorithm. If the model residue did not pass the LjungBox test for lack of autocorrelation at the 0.05 significance level, the first element of the training sample was discarded and the model was trained again until it passed the test. In the case of $\operatorname{ARFIMA}(p, d, q)$, the orders $p, q$ in the range from 1 to 2 were moved (according to [Balagula, 2020], the ARFIMA models of higher orders have a tendency to retraining), and the model with the lowest value of the BIC information criterion was selected. ARFIMA models that did not pass the following tests were eliminated: 1) the share of significant at the level of 0.05 model coefficients is more than $0.5 ; 2$ ) there is no autocorrelation in the residuals at the level of significance 0.05 according to the Ljung-Box test; 3 ) the residuals are normally distributed at the level of significance 0.05 according to the Shapiro-Wilk test. All adequate models generated a forecast of 12 values forward, after which the forecast error was estimated for the MAE metric: $M A E=\frac{1}{T} \sum_{t=1}^{T}\left|r_{t}-r_{t}^{*}\right|$, where $T$ is the number of forecast values (in our case is 12), $r_{t}$ is the true (realized) value of profitability, $r_{t}{ }^{*}$ is the value of profitability predicted by the model.

\section{Results}

The results of modeling and forecasting of series are given in Table 1.

As you can see, the average absolute error of the ARFIMA-GARCH model differs slightly from that of ARFIMA on the data of both types - within the margin of error (the difference in sample averages is 0.0002 for model data and 0.002 for real data). To verify the statistical significance of this observed difference, we used a non-parametric Mann-Whitney $U$-test (the choice of this criterion instead of the Student's t-test is due to the non-normal character of the MAE error distribution). The results showed that in both cases there is not enough reason to reject the null hypothesis about the absence of significant differences in samples (model data: $p$-value $=$ 0.36 , real data: $p$-value $=0.43$ ). Nevertheless, the GARCH fractal model showed a smaller error in both cases, and the difference in its favor exceeded by an order of magnitude the difference for model data when forecasting series of stock yield. This can be explained by the fact that the process of "pure" fractal Brownian motion does not describe real financial series with high peaks, "heavy tails", conditional heteroscedasticity, etc., and the GARCH model managed to catch these features better on real data.

Let's turn to the results of portfolio formation using different predictive models presented in Table 2. In total, 66 combinations of 2 assets were formed out of 12 assets, from which the portfolios were formed. To simulate portfolios from artificial "assets" were also randomly selected 12 series of previously generated.

As can be seen from Table 2, despite the absence of statistically significant difference in accuracy of forecasts using ARFIMA and ARFIMA-GARCH models according to the Mann-Whitney test, the characteristics of the obtained portfolios are different.

Model data. While maximizing the profitability by 2.7 times, portfolios formed with the use of ARFIMA-GARCH have higher profitability. At the same time, the standard deviation of

Average errors in data forecasts using different models

\begin{tabular}{|l|c|c|}
\hline \multirow{2}{*}{ Model family } & \multicolumn{2}{|c|}{ MAE value * } \\
\cline { 2 - 3 } & $\begin{array}{c}\text { Artificial series } \\
\text { (quantity is 1000) }\end{array}$ & $\begin{array}{c}\text { Series of share yields } \\
\text { (quantity is 12) }\end{array} *$ \\
\hline ARFIMA $(p, d, q)$ & $0.028585 \pm 0.000821$ & $0.047531 \pm 0.008496$ \\
\hline ARFIMA $(p, d, q)$-GARCH $(1,1)$ & $0.028417 \pm 0.000858$ & $0.045421 \pm 0.010125$ \\
\hline
\end{tabular}

Notes. Compiled by the author. * - an average value with $99 \%$ confidence interval for mathematical expectation of unknown distribution law is given; ** - shares with tickers CHMF, FEES, GAZP, MAGN, MGNT, NLMK, NVTK, ROSN, TATN, TATNP, TRNFP, UPRO; for the assets AFLT, GMKN, LKOH, MTSS, PIKK, PLZL, SNGS, SNGSP it was not possible to build the verified ARFIMA and/or ARFIMA-GARCH models. 
Characteristics of portfolios formed in different ways *

\begin{tabular}{|c|c|c|c|c|}
\hline Model family & $\begin{array}{l}\text { Target function of the portfolio } \\
\text { optimization task }\end{array}$ & Yield ** & Risk ** & Sharp ratio ** \\
\hline \multicolumn{5}{|c|}{ Model «assets» } \\
\hline \multirow[t]{3}{*}{$\operatorname{ARFIMA}(p, d, q)$} & Maximization of yield & $0.029 \pm 0.043$ & $0.145 \pm 0.007$ & $0.147 \pm 0.328$ \\
\hline & Minimizing risk & $0.065 \pm 0.047$ & $0.105 \pm 0.008$ & $0.523 \pm 0.412$ \\
\hline & Maximizing the Sharp ratio & & & $0.326 \pm 0.368$ \\
\hline \multirow{3}{*}{$\begin{array}{l}\operatorname{ARFIMA}(p, d, q)- \\
\operatorname{GARCH}(1,1)\end{array}$} & Maximization of yield & $0.109 \pm 0.056$ & $0.153 \pm 0.006$ & $0.636 \pm 0.375$ \\
\hline & Minimizing risk & $0.065 \pm 0.047$ & $0.105 \pm 0.008$ & $0.523 \pm 0.412$ \\
\hline & Maximizing the Sharp ratio & & & $0.814 \pm 0.339$ \\
\hline \multicolumn{5}{|c|}{ Real financial assets } \\
\hline \multirow[t]{3}{*}{$\operatorname{ARFIMA}(p, d, q)$} & Maximization of yield & $0.025 \pm 0.041$ & $0.763 \pm 0.084$ & $0.062 \pm 0.072$ \\
\hline & Minimizing risk & $0.097 \pm 0.056$ & $0.547 \pm 0.081$ & $0.362 \pm 0.200$ \\
\hline & Maximizing the Sharp ratio & & & $0.126 \pm 0.116$ \\
\hline \multirow{3}{*}{$\begin{array}{l}\operatorname{ARFIMA}(p, d, q)- \\
\operatorname{GARCH}(1,1)\end{array}$} & Maximization of yield & $0.050 \pm 0.048$ & $0.656 \pm 0.086$ & $0.157 \pm 0.143$ \\
\hline & Minimizing risk & $0.097 \pm 0.056$ & $0.547 \pm 0.081$ & $0.362 \pm 0.200$ \\
\hline & Maximizing the Sharp ratio & & & $0.215 \pm 0.166$ \\
\hline
\end{tabular}

Notes. Compiled by the author. * - the best performance within the comparison of models is highlighted in bold; $* *$ - an average value with $99 \%$ confidence interval for mathematical expectation of unknown distribution law is given.

profitability is only $6 \%$ higher. The values of the Sharp ratio show that the GARCH portfolio significantly wins in terms of the yield to risk ratio. While minimizing the risk, the portfolio parameters coincided, which is explained by the small share of the impact of the forecast yield for 2019 on the value of the standard deviation of annual returns, calculated over the entire history of the series. Optimization on the Sharp ratio also showed the advantage of the GARCH portfolio.

Real data. In maximizing the profitability, GARCH portfolios showed twice as high profitability, while the risk was also lower than ARFIMA portfolios. GARCH portfolios are still winning in terms of yield to risk ratio. While minimizing the standard deviation, the situation is like the case with the model data - the characteristics of portfolios are the same. At the maximization of the Sharp ratio GARCH portfolio showed 1.7 times the best ratio of return to risk.

When solving the task of maximizing the portfolio profitability without additional restrictions on the portfolio characteristics, the algorithm, as a rule, includes one of the most profitable assets in the portfolio, it is it that provides the maximum profitability. It can be stated that when optimizing the portfolio on the basis of forecast data obtained using the ARFIMA-GARCH model, the most profitable asset was identified more often on average than when using the ARFIMA model.

To check the presence of significant differences in the series of portfolio returns obtained with the help of different models, MannWhitney $U$-test was used, which showed the following: on the model data the portfolio returns differ significantly at the significance level 0.01 ( $p$-value is 0.00 ), on the real data no significant differences were found ( $p$-value is 0.21 ).

Figure 2 shows the obtained yield values for each of the 66 asset combinations.

According to Figure 2, it is noticeable that the ARFIMA-GARCH model revealed a more profitable asset in most cases. On real data, its advantage is not so pronounced, which led to failure of the $U$-test, but remains.

\section{Conclusion}

A study was conducted to test the hypothesis that the formation of investment portfolios based on predicted returns obtained using fractal models with conditional heteroscedasticity (ARFIMAGARCH), allows to obtain portfolios with better characteristics than those obtained using ARFIMA model. The conducted computational experiment on artificial and real market data showed that the hypothesis is not rejected, ARFIMA-GARCH 

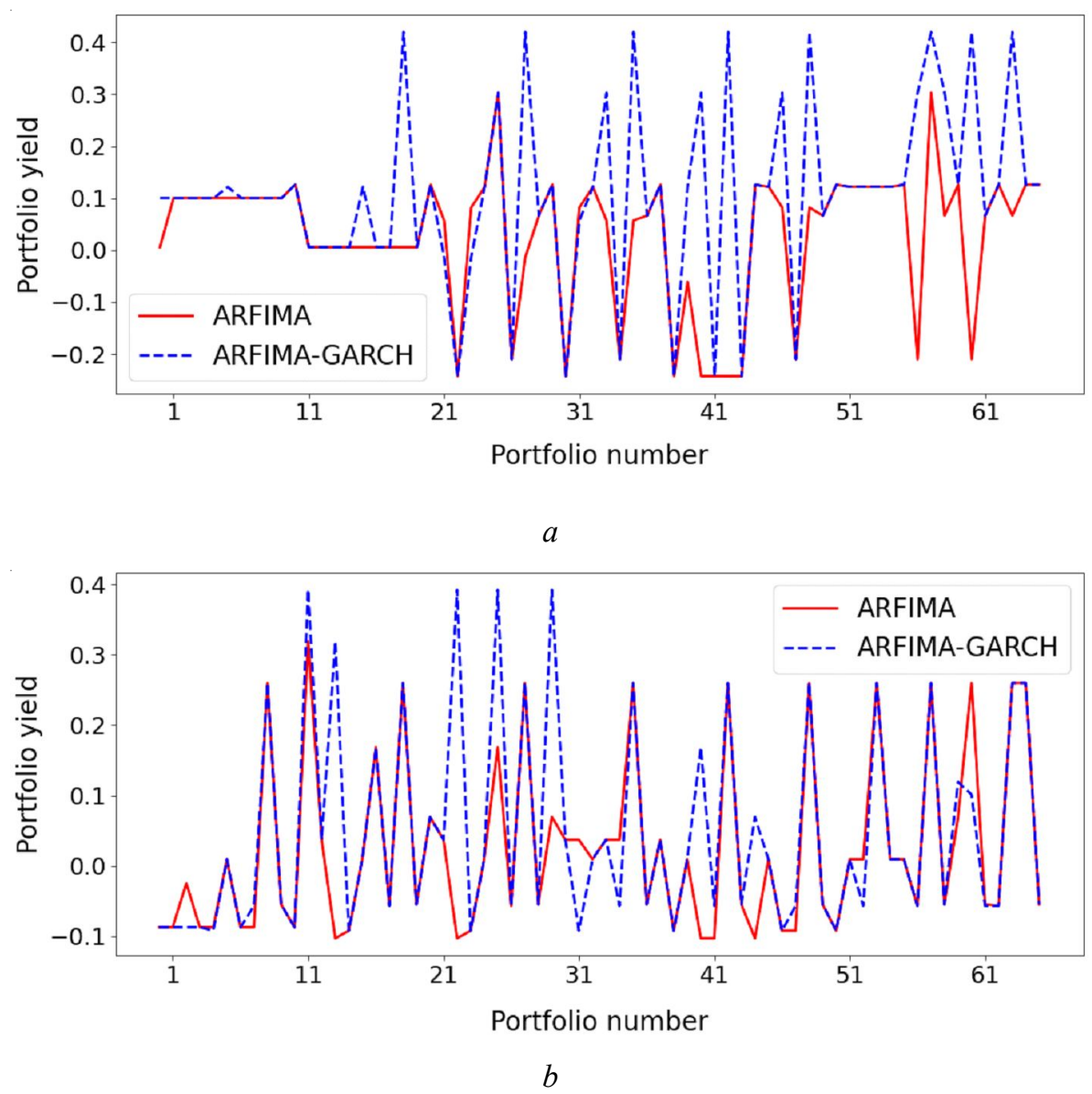

Fig. 2. Yields of portfolios formed using model data (a) and real financial data (b)

Note. Compiled by the author.

models really allows improving the characteristics of portfolios. Therefore, in our opinion, this direction in the study of new ways to form investment portfolios is promising.

In further research it is necessary to increase the number of assets in portfolios in order to better utilize the diversification principle, and test the hypothesis of superiority of ARFIMAGARCH with more modern portfolio models, improved relative to the classical Markowitz model. In the future, the considered method of forming portfolios can become one of the items of the methodology of forming investment portfolios with the use of econometric models and fractal analysis that is under development.

\section{REFERENCES}

Aouni B., Doumpos M., Pérez-Gladish B., Steuer R. On the Increasing Importance of Multiple Criteria Decision Aid Methods for Portfolio Selection. Journal of the Operational Research Society,
2018, vol. 69, pp. 1525-1542. DOI: 10.1080/ 01605682.2018 .1475118 .

Balagula Yu.M. Prognozirovanie sutochnyh cen na ORJeM RF s pomosh'ju modeli ARFIMA [Forecasting Daily Spot Prices in the Russian Electricity Market With the Arfima Model]. Prikladnaja Jekonometrika [Applied Econometrics], 2020, vol. 57, pp. 89-101. DOI: $10.22394 / 1993760120205789101$.

Bollerslev T. Generalized Autoregressive Conditional Heteroscedasticity. Journal of Econometrics, 1986, vol. 31, pp. 307-327.

Chichaev I.A., Popov V.Yu. Ob odnom podhode k vychisleniju indeksa Hersta finansovyh vremennyh rjadov $i$ ih approksimacii fraktal'nym brounovskim dvizheniem [About One Approach for Financial Time Series' Hurst Index Computation and Their Approximation Using Fractal Brownian Motion]. Sovremennye problemy nauki i obrazovaniya [Modern Problems of Science and Education], 2013, no. 2. URL: https://www.science-education.ru/ $\mathrm{ru} /$ article/view?id=8698 $($ accessed 14 March 2021). 
Garafutdinov R., Gurova E. The Formation of Investment Portfolios Based on Forecasted Income With the Use of Fractal Models. Mathematical Modeling, 2019, no. 3, pp. 86-88.

Gubanova E.V., Sokolova I.S., Solovyova S.V. Ispol'zovanie finansovyh instrumentov pri formirovanii jeffektivnogo portfelja cennyh bumag [Use of Financial Instruments When Forming the Effective Portfolio of Securities]. Vestnik NGIEI [Bulletin NGIEI], 2016, no. 9 (64), pp. 123-137.

Markowitz H. Portfolio Selection. Journal of Finance, 1952, no. 7, pp. 77-91.

Semenenko M.G. Model' Markovica: matematicheskie aspekty i komp'juternaja realizacija [Markowitz Model: Mathematical Aspects and Computer Implementation]. Sovremennye informacionnye tehnologii $i$ IT-obrazovanie [Modern Information Technologies and IT-Education], 2015, no. 11, pp. 306-309.
Simonov P.M., Garafutdinov R.V. Modelirovanie i prognozirovanie dinamiki kursov finansovykh instrumentov s primeneniem ekonometricheskikh modelei i fraktal'nogo analiza [Modeling and Forecasting of Financial Instruments Dynamics Using Econometrics Models and Fractal Analysis]. Vestnik Permskogo universiteta. Ser. «Jekonomika» [Perm University Herald. Economy], 2019, vol. 14, no. 2, pp. 268-288. DOI: 10.17072/1994-9960-2019-2-268-288.

Simonov P.M., Akhunyanova S.A. Sravnitel'nyj analiz metodik AR-GARCH i $p$-adicheskogo prognozirovanija volatil'nosti finansovogo rynka [Comparative Analysis of AR-Garch and $p$-adic Methods of the Prediction of the Financial Market Volatility]. Vestnik Permskogo universiteta. Ser. «Jekonomika» [Perm University Herald. Economy], 2019, vol. 14, no. 1, pp. 69-92. DOI: 10.17072/1994-9960-2019$1-69-92$.

\section{Information About the Author}

Robert V. Garafutdinov, Postgraduate Student, Department of Information Systems and Mathematical Methods in Economics, Perm State University, Bukireva St, 15, 614990 Perm, Russian Federation, rvgarafutdinov@gmail.com, https://orcid.org/0000-0002-2130-9352

\section{Информация об авторе}

Роберт Викторович Гарафутдинов, аспирант кафедры информационных систем и математических методов в экономике, Пермский государственный национальный исследовательский университет, ул. Букирева, 15, 614990 г. Пермь, Российская Федерация, rvgarafutdinov@gmail.com, https://orcid.org/0000-0002-2130-9352 